\title{
Monoclonal Antibody Characterization of a Chymotrypsin-like Molecule on Neutrophil Membrane Associated with Cellular Activation
}

\author{
Charles H. King, Cynthia Haimes Goralnik, Paula J. Kleinhenz, John A. Marino, John R. Sedor, and Adel A. F. Mahmoud \\ Department of Medicine, Case Western Reserve University; University Hospitals \\ and Cleveland Metropolitan General Hospital, Cleveland, Ohio 44106
}

\begin{abstract}
Monoclonal antibody 1-15 (Ab 1-15), is a murine anti-human neutrophil (PMN) IgG I $_{1}$ that inhibits PMN effector responses to $\boldsymbol{N}$-formyl-met-leu-phe (FMLP) and phorbol myristate acetate. In this study, the effects of Ab 1-15 on PMN membrane-related functions were characterized: Ab 1-15 inhibited PMN superoxide $\left(\mathrm{O}_{2}^{-}\right)$response to FMLP by $60 \%(P<0.005)$ without effect on the onset or duration of $\mathrm{O}_{2}^{-}$production. This inhibition of $\mathrm{O}_{2}^{-}$ response was associated with a significant inhibition of PMN chymotrypsin-like, but not trypsin-like, protease activity. Cell fractionation studies indicated the presence of an Ab 1-15-inhibitible, chymotryptic neutral protease activity in PMN membranes. In studies of Ab 1-15 effects on membrane-related second messenger pathways, Ab 1-15 augmented both FMLP- and isoproterenol-induced intracellular cAMP accumulation, whereas $\alpha$-chymotrypsin decreased PMN cAMP response to these stimuli. Our data suggest that the function-inhibiting, anti-PMN monoclonal Ab 1-15 defines a PMN chymotryptic enzyme on the membrane surface that is involved in regulation of two membrane-related functions, $\mathrm{O}_{2}^{-}$generation and cAMP generation.
\end{abstract}

\section{Introduction}

Neutrophil polymorphonuclear leukocyte (PMN) ${ }^{1}$ activation depends on the function of multiple membrane components: in response to peptide stimuli (e.g., the chemotactic factor $N$-formylmet-leu-phe [FMLP]), activation occurs as a consequence of stimulus binding to receptors on the cell surface (1-4). Immediate, secondary, stimulus-induced changes in PMN metabolism include the activation of phospholipases (5-7), which cause the release of polyphosphoinositides and arachidonic acid, and the activation as well as down-regulation of adenylate cyclase activity $(8,9)$. These and other early membrane events culminate, after

Portions of this work were presented to the 77th Annual Meeting of the American Society for Clinical Investigation and were published in abstract form (1985, Clin. Res., 33:564A).

Address reprint requests to Dr. King, Division of Geographic Medicine, Department of Medicine, University Hospitals of Cleveland, Cleveland, OH 44106. 1986.

Received for publication 14 May 1986 and in revised form 2 December

1. Abbreviations used in this paper: Ab 1-15, monoclonal antibody 115; ATEE, $N$-acetyl L-tyrosine ethyl ester; BTEE, benzoyl L-tyrosine ethyl ester, FMLP, $N$-formyl-met-leu-phe; HBSS, Hanks' balanced salt solution; $N_{\mathrm{i}}$, inhibitory nucleotide regulatory protein; PMN, polymorphonuclear leukocytes; TAME, tosyl L-arginine methyl ester.

J. Clin. Invest.

(c) The American Society for Clinical Investigation, Inc.

0021-9738/87/04/1091/08 $\$ 1.00$

Volume 79, April 1987, 1091-1098 a brief lag period, in detectable increases in important cellular effector functions, including the generation of superoxide anion $(10,11)$.

To date, many of the molecular mechanisms that couple stimulus exposure to subsequent activation of PMN membrane metabolism remain unknown. Research has been limited by problems confronted in precisely identifying, isolating, and modifying the individual membrane components that are involved in PMN activation. Recently, pertussis toxin, (islet cell activating factor, a highly specific inhibitor of the inhibitory guanine nucleotide regulatory protein $\left.\left[N_{\mathrm{i}}\right]\right)$, has been used to define the significant role played by the $N_{\mathrm{i}}$ in the activation of PMN effector responses $(9,12-14)$. In a similar fashion, studies using function-inhibiting monoclonal anti-PMN antibodies are beginning to dissect the functions of specific PMN surface antigens (3, 15-19).

In this paper, we describe the ability of a function-inhibiting, PMN-specific monoclonal antibody, monoclonal antibody 1-15 (Ab 1-15), to inhibit PMN membrane-associated chymotryptic activity in conjunction with its inhibition of FMLP-induced superoxide generation. Although the role of proteases in PMN activation has remained controversial for the past two decades (20-26), evidence from many mammalian cell systems now suggests that endogenous membrane proteases and exogenous proteases significantly modify membrane structure and function during the process of cellular activation. Significant proteaseinduced changes include alterations of receptor expression on platelets (27) and on neuronal cells (28), alteration of cAMP accumulation in platelets, kidney cells, and fibroblasts $(29,30)$, and alterations in vascular endothelial cell adhesiveness (31). In particular, protease treatment has been shown to alter the function of the regulatory $N_{\mathrm{i}}$ molecule in diverse cell systems (29, 30). Furthermore, exposure to chymotryptic proteases, including neutrophil-derived cathepsin $\mathrm{G}$, has been shown to augment the stimulus-induced effector responses of monocytes, B cells, and neutrophils (32-34).

We previously reported that PMN preincubation with $\mathrm{Ab}$ 1-15 inhibits cellular responses to FMLP and phorbol myristate acetate in assays of superoxide generation (19). Ab 1-15 also inhibits PMN degranulation and adhesive responses to FMLP, but, notably has no effect on cell chemotactic response to this peptide. The target PMN surface antigen for Ab 1-15 is an $M_{\mathrm{r}}$ $150,000-180,000$ molecule by SDS polyacrylamide gel electrophoresis (PAGE).

In the current investigation, we detail the effects of $A b$ 1-15 on FMLP-induced superoxide generation, and determine that this inhibitory function is associated with antibody-mediated inhibition of a chymotryptic activity within purified PMN membrane. Although chemical chymotrypsin substrates failed to protect cells from the inhibitory effects of $A b 1-15$, it was found that $\mathrm{Ab}$ 1-15 acts as an uncompetitive inhibitor of chymotrypsin activity. Because chymotrypsin exposure has been 
shown to modify the function of the $N_{\mathrm{i}}$ molecule in other cell systems, and because the $N_{\mathrm{i}}$ molecule has been shown to play an important role in mediating FMLP-induced cell activation, we examined the effects of $\mathrm{Ab}$ 1-15 (a protease inhibitor), and the effects of chymotrypsin on cAMP accumulation in response to two different receptor-dependent stimuli, FMLP and isoproterenol. Ab 1-15 augmented, and chymotrypsin decreased cAMP accumulation in response to either isoproterenol or FMLP stimulation. However, pertussis toxin had no effect on chymotrypsin's inhibition of CAMP response to FMLP, suggesting that this effect is unrelated to $N_{\mathrm{i}}$ molecule activation. Our findings indicate that the $\mathrm{Ab}$ 1-15 target antigen/protease is involved in modulating two important events associated with PMN activation, superoxide generation, and inhibition of cAMP accumulation. The precise targets of this activation-associated protease remain to be defined.

\section{Methods}

Chemicals. $10 \mathrm{mM}$ phosphate-buffered normal saline, bovine serum albumin (BSA; radioimmunoassay [RIA] grade), horse heart ferricytochrome C (Type III), superoxide dismutase, FMLP, benzoyl-L-tyrosine ethyl ester (BTEE), $N$-acetyl-L-tyrosine ethyl ester (ATEE), tosyl-L-arginine methyl ester (TAME), isoproterenol, crystalline bovine $\alpha$-chymotrypsin (EC 3.4.21.1), bovine trypsin (EC 3.4.21.4, tosyl phenyl chlormethyl ketone-treated), xanthine, and xanthine oxidase were purchased from Sigma Chemical Co. (St. Louis, MO). 2,6,10,14 tetra methyl pentadecane (Pristane) was obtained from Aldrich Chemical Co. (Milwaukee, WI). Ficoll-Hypaque and dextran were obtained from Pharmacia Fine Chemicals, Inc. (Piscataway, NJ) and Hanks' balanced salt solution (HBSS) with and without calcium and magnesium was obtained from KC Biologicals Inc. (Lenexa, KS). ${ }^{125}$ I-labeled $F\left(a^{\prime}\right)_{2}$ fragments of sheep anti-mouse IgG $(10 \mathrm{mCi} / \mathrm{mg})$ were purchased from New England Nuclear (Boston, MA). ${ }^{125}$ I-tyrosine methylester of cAMP was obtained from Becton-Dickinson \& Co. (Paramus, NJ). Isobutyl methylxanthine was obtained from Calbiochem-Behring Corp. (La Jolla, CA). Purified pertussis toxin was a gift of Dr. Eric Hewlett (University of Virginia, Charlottesville, VA).

In control studies the solvents used to prepare reagents (ethanol or dimethylsulfoxide) had no effect on cell viability (as assessed by trypan blue exclusion) (35) or cell function in vitro.

Preparation and characterization of $A b$ 1-15. Purified monoclonal Ab 1-15 was prepared from malignant hybridoma ascites fluid as previously described $(19,36,37)$. Cell function assays were performed using either purified $\operatorname{lgG}$ or $\mathrm{F}\left(\mathrm{ab}^{\prime}\right)_{2}$ fragments prepared from IgG by pepsin digestion (38). Some functional studies were performed using Fab' $^{\prime}$ monomer prepared by reduction of $\mathrm{F}\left(\mathrm{ab}^{\prime}\right)_{2}$ fragments with 2-mercaptoethanol (38). Similarly processed irrelevant $\mathrm{IgG}_{1}$ murine monoclonal antibody was used as control in all studies. Protein determinations were carried out using the method of Lowry et al. (39).

Preparation of cells. Granulocytes were isolated from heparinized venous blood obtained from healthy adult donors by density centrifugation on Ficoll-Hypaque followed by dextran sedimentation and hypotonic lysis of contaminating erythrocytes (40). To avoid cell activation during purification, all washings of cells were performed in $\mathrm{Ca}^{+2}$ - and $\mathrm{Mg}^{+2}$-free HBSS at $4^{\circ} \mathrm{C}$; complete HBSS (containing $\mathrm{Ca}^{+2}$ and $\mathrm{Mg}^{+2}$ ) was used as final buffer for functional studies. Purity of neutrophil populations was assessed by Wright-Giemsa staining and was $>95 \%$. Viability was determined by trypan blue exclusion and was also $>95 \%$. All PMN preparations were used within $4 \mathrm{~h}$ of isolation.

Measurement of superoxide production. $\mathrm{O}_{2}^{-}$generation was assayed spectrophotometrically as superoxide dismutase-inhibitable reduction of ferricytochrome $C$ using an extinction coefficient of $2.1 \times 10^{4} \mathrm{M}^{-1}$ $\mathrm{cm}^{-1}$ (41). One million PMNs in $50 \mu$ l HBSS were combined with 500 $\mu \mathrm{l}$ cytochrome $\mathrm{C}(1.2 \mathrm{mg} / \mathrm{ml}$ in HBSS $)$ and $100 \mu \mathrm{l}(500 \mu \mathrm{g})$ control or antineutrophil antibody in a cuvette. The volume was brought up to
$1,000 \mu \mathrm{l}$ with HBSS and the mixture was incubated for $2 \mathrm{~min}$ at $37^{\circ} \mathrm{C}$. $10 \mu$ FMLP (final concentration $5 \times 10^{-7} \mathrm{M}$ ) was then added, the solution mixed, and absorbance recorded every minute. For experiments in which the effects of BTEE or ATEE were evaluated, cells were preincubated with various concentrations of these reagents for $2 \mathrm{~min}$ at $37^{\circ} \mathrm{C}$ before starting the assay.

Detection of protease activity in intact PMNs and their subcellular fractions. Chymotrypsin activity was measured by hydrolysis of BTEE as previously described (42). Five million PMNs were suspended in 1 $\mathrm{ml} \mathrm{0.00107} \mathrm{M} \mathrm{BTEE} \mathrm{and} \mathrm{incubated} \mathrm{on} \mathrm{a} \mathrm{shaker} \mathrm{for} 30 \mathrm{~min}$ at $37^{\circ} \mathrm{C}$. The cells were then pelleted and the absorbance at $256 \mathrm{~nm}$ of the supernatant was compared with that of substrate that had not been exposed to PMNs. Trypsin activity was determined using $0.01 \mathrm{M}$ TAME as substrate and readings were taken at $247 \mathrm{~nm}$ (43). The effect of antibody on protease activity was determined by incubating cells and substrate in the presence of either $250 \mu \mathrm{g}$ control antibody or $250 \mu \mathrm{g} \mathrm{Ab} \mathrm{1-15.}$

For subcellular localization of cell chymotrypsin activity, nitrogen cavitation, and differential centrifugation at $1,000,27,000$, and 105,000 $g$ (as described by Klempner et al. [44]) were used to prepare cell fractions enriched, respectively, for nuclei, lysosomal granules, and plasma membrane. Membrane purification was confirmed using PMN surface labeling with ${ }^{3} \mathrm{H}$-concanavalin $\mathrm{A}$ as described by Record et al. (45). In our studies of chymotrypsin activity of PMN fractions, the only modification of the fractionation protocol was the omission of cell pre-exposure to protease inhibitors. Protease activity of solubilized cell components were measured as described below for bovine chymotrypsin.

Characterization of $A b$ 1-15 interaction with soluble proteases. To determine the effect of $\mathrm{Ab}$ 1-15 on protease activities in cell-free systems, chymotrypsin stock of $1 \mathrm{mg} / \mathrm{ml}$ in $1 \mathrm{mM} \mathrm{HCl}$ was diluted 1:50 with 1 $\mathrm{mM} \mathrm{HCl}$ just before use. Equal volumes $(100 \mu \mathrm{l})$ of enzyme and antibody (25-500 $\mu \mathrm{g}$ ) were preincubated on ice for $15 \mathrm{~min}$, with shaking every 5 min. $200 \mu$ l of chymotrypsin buffer $(0.08 \mathrm{M}$ Tris- $\mathrm{HCl}$ [pH 7.8] containing $0.1 \mathrm{M} \mathrm{CaCl}_{2}$ ) were added and the contents were mixed with BTEE substrate. Absorbance at $256 \mathrm{~nm}$ was followed every minute for $10 \mathrm{~min}$ (43). Trypsin was used at $10 \mu \mathrm{g} / \mathrm{ml}$ freshly diluted in trypsin buffer $(0.05$ $\mathrm{M}$ Tris and $0.01 \mathrm{M} \mathrm{CaCl}_{2}$ [pH 8.1]) from a $1 \mathrm{mg} / \mathrm{ml}$ stock. Antibody inhibition studies were carried out as above using the appropriate trypsin buffer and substrate ( $0.01 \mathrm{M}$ TAME); the spectrophotometer readings were performed every $40 \mathrm{~s}$ at $247 \mathrm{~nm}$ (43). To confirm specific Ab 1-15 recognition of chymotrypsin-like molecules, Ab 1-15 immunoprecipitation of ${ }^{125}$ I radiolabeled chymotrypsin (prepared by chloroamine-T method (46) using carrier-free $\mathrm{Na}^{125}$ Iodide [New England Nuclear]) was performed as previously described (19) using a precipitating sheep antimouse IgG second antibody (Cappel Laboratories, Cochraneville, PA).

Assay of intracellular cAMP levels. For assay of Ab 1-15 effects on cAMP production by stimulated and unstimulated cells, $10^{6} \mathrm{PMN}$ preincubated with control IgG, Ab 1-15, pertussis toxin or medium were added to prewarmed HBSS containing $0.5 \mathrm{mM}$ isobutylmethylxanthine and appropriate stimulus ( $10 \mu \mathrm{M}$ isoproterenol or $1 \mu \mathrm{M}$ FMLP) or control medium. Intracellular cAMP accumulation was measured at 0-5 min by RIA (as previously described [47]) after extraction with TCA. Results were normalized for protein content, and are expressed as femtomoles cAMP per microgram protein or as $\triangle \mathrm{CAMP}$ accumulation $=($ experimental - control)/control $\times 100$ (\%). In studies of PMN cAMP response with chymotrypsin and/or pertussis toxin, control experiments were run in the presence of equal microgram amounts of BSA.

Data analysis. Differences between experimental groups were tested for statistical significance using $t$ test for unpaired data.

\section{Results}

Effect of Ab 1-15 on PMN superoxide production. To characterize the effects of $A b 1-15$ and its $\left(\mathrm{Fab}^{\prime}\right)_{2}$ dimer and $\mathrm{F}\left(\mathrm{ab}^{\prime}\right)$ monomer on cell respiratory burst, PMNs were incubated in the presence of varying concentrations of $A b$ 1-15 or irrelevant $\operatorname{IgG}_{1}$, and assayed for superoxide production in response to FMLP. Preliminary studies established that in $25-500 \mu \mathrm{g} / \mathrm{ml}$ of control 
irrelevant IgG, $0.5 \mu \mathrm{M}$ FMLP afforded $90-95 \%$ of maximal cell superoxide response ( $12 \mathrm{nmol} / 10^{6} \mathrm{PMN}$ per $10 \mathrm{~min}$ ) without impairment of cell viability. Subsequent antibody inhibition studies were performed at this concentration of FMLP. In medium containing $500 \mu \mathrm{g} / \mathrm{ml}$ control antibody, superoxide production by $10^{6}$ PMNs was $10.9 \pm 3.7 \mathrm{nmol} / 10 \mathrm{~min}$, whereas $\mathrm{PMN}$ exposed to $500 \mu \mathrm{g} / \mathrm{ml}$ of $\mathrm{Ab} \mathrm{1-15}$, gave an $\mathrm{O}_{2}^{-}$response of $4.3 \pm 1.7$ $\mathrm{nmol} / 10 \mathrm{~min}$ (mean of three separate experiments). This $60 \%$ reduction in superoxide response was significantly different at $P<0.005$ level. Furthermore, PMN incubation with Ab 1-15 was noted to reduce significantly the maximum rate of cell superoxide production in response to FMLP $(1.1 \mathrm{nmol} / \mathrm{min}$ in comparison with $2.6 \mathrm{nmol} / \mathrm{min}$ for cells incubated in control antibody, $P<0.01$ ) without having a significant effect on the onset or duration of cell activation (Fig. $1 A$ ). In dose-response studies, the degree of Ab 1-15-mediated inhibition of FMLPinduced superoxide generation was $19 \%$ at $0.14 \mu \mathrm{M}(25 \mu \mathrm{g} / \mathrm{ml})$ and increased to a maximum of $60 \%$ at an IgG concentration of $2.8 \mu \mathrm{M}(500 \mu \mathrm{g} / \mathrm{ml})$ (Fig. $1 B)$. Equimolar concentrations $(0.14 \mu \mathrm{M})$ of $\mathrm{F}\left(a b^{\prime}\right)_{2}$ dimer and $\mathrm{F}\left(\mathrm{ab}^{\prime}\right)$ monomer derived from Ab 1-15 provided significantly greater inhibition of $\mathrm{PMN} \mathrm{O}_{2}^{-}$ production than intact Ab 1-15 IgG (Fig. 1C). Additional experiments showed that Ab 1-15 did not directly stimulate cell superoxide production, and that it was not a scavenger of $\mathrm{O}_{2}^{-}$in the cell-free xanthine-xanthine oxidase-generating system (data not shown).

Effect of Ab 1-15 on neutrophil-associated protease activity. We next explored the possibility that the inhibitory effects of Ab 1-15 on superoxide production were secondary to a suppres-
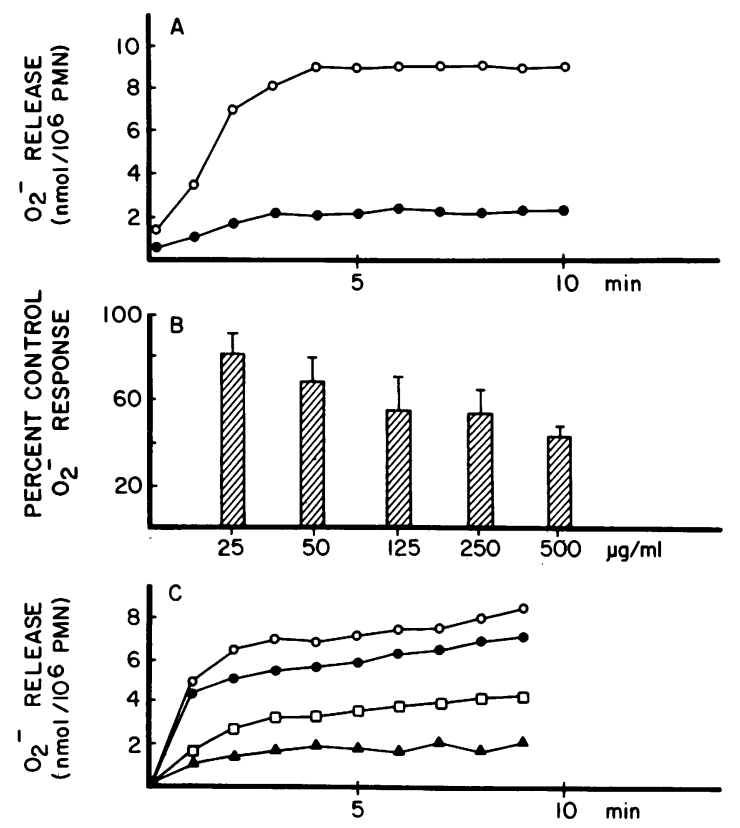

Figure 1. Effects of Ab 1-15 on PMN superoxide response. $A$, onset and duration of $\mathrm{O}_{2}^{-}$generation in FMLP-stimulated PMN exposed to

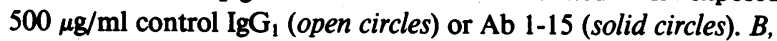
dose-response of $\mathrm{Ab}$ 1-15-mediated inhibition of $\mathrm{O}_{2}^{-}$production in response to fmet-leu-phe. $C$, effects of different forms of $A b$ 1-15 in equimolar concentrations. Open circles, control IgG; solid circles, IgG Ab 1-15; open squares, $\mathrm{F}\left(\mathrm{ab}^{\prime}\right)_{2}$; solid triangles, $\mathrm{F}\left(\mathrm{ab}^{\prime}\right)$. Data points for $A$ and $C$, means of duplicate determinations from one of three similar experiments. Data in $B$, means $\pm S E$ for three to five experiments at each antibody concentration. sion of cell surface protease activity. These studies were undertaken because $\mathrm{Ab}$ 1-15-mediated inhibition of PMN superoxide response resembled PMN inhibition induced by inhibitors of serine proteases (21-23). Intact PMNs were assayed for chymotrypsin- and trypsin-like activity in the presence of either control antibody or Ab 1-15. Both types of enzyme activity were detectable in PMNs incubated with irrelevant $\operatorname{IgG}_{1}$ monoclonal, (a mean of $2.7 \pm 0.6$ milliU chymotrypsin activity and $0.8 \pm 0.3$ milliU trypsin activity/million PMNs). Cell exposure to Ab 115 resulted in a $70 \%$ decrease in detectable cell-associated chymotrypsin activity $(0.8 \pm 0.2$ milliU, mean $\pm S E$ of three experiments, $P<0.01$ ), while trypsin activity was not significantly diminished (Table I).

To examine the subcellular localization of PMN proteases inhibited by Ab 1-15, subcellular fractions of PMN were prepared by nitrogen cavitation and differential sedimentation (without the use of protease inhibitors). Table II summarizes the distribution of protein recovery and marker enzymes. Pellet $1(1000 \mathrm{~g})$, containing nuclei and undisrupted cells, showed a mixture of all marker enzymes. Pellet $2(27,000 \mathrm{~g})$ was enriched for the lysosomal enzyme marker, lysozyme, but also contained a significant amount of the membrane markers alkaline phosphatase and ${ }^{3} \mathrm{H}$-Con $\mathrm{A}$. By contrast, pellet $3(105,000 \mathrm{~g})$ was significantly enriched $(P$ $<0.05$ ) for alkaline phosphatase and ${ }^{3} \mathrm{H}-\mathrm{Con} \mathrm{A}$ but had no detectable lysozyme activity, indicating relatively pure membrane fractionation. Chymotrypsin-like activity (BTEE hydrolysis at $\mathrm{pH}$ 7.8) was demonstrated in all recovered fractions, including the washed and resuspended membrane-containing pellet 3 . Of note, the mean chymotrypsin-like activity of pellet $3(0.16 \mathrm{mU} / \mathrm{mg}$ protein) was significantly greater $(P<0.05)$ than the activity of its supernatant $(0.04 \mathrm{mU} / \mathrm{mg}$ protein). Chymotrypsin-like activity in the membrane was completely inhibited (100\%) by $100 \mu \mathrm{g} / \mathrm{ml}$ $\mathrm{Ab}$ 1-15, whereas equivalent enzyme activities diluted from the resuspended pellet 2 (containing granules) and the cytosolic fraction were only partially inhibited by the same concentration of antibody (56 and 59\%, respectively).

Effect of chymotrypsin synthetic substrates on inhibition of superoxide production by $A b$ 1-15. We subsequently examined whether chymotrypsin-specific substrates could block the Ab 115-mediated inhibition of $\mathrm{O}_{2}^{-}$production by FMLP-stimulated PMN. It was first confirmed that concentrations $\geq 10 \mu \mathrm{M}$ BTEE and $\geq 50 \mu \mathrm{M}$ ATEE were themselves effective inhibitors of PMN superoxide production (23). In our attempts at substrate protection of membrane protease activity, PMN were exposed to

Table I. Ab 1-15 Effects of Trypsin- and Chymotrypsin-like Protease Activities of Intact Unstimulated PMN

\begin{tabular}{lll}
\hline PMN co-incubation & $\begin{array}{l}\text { Chymotrypsin-like* } \\
\text { activity }\end{array}$ & $\begin{array}{l}\text { Trypsin-like } \\
\text { activity }\end{array}$ \\
\hline & $m U / 10^{6} P M N$ & $m U / 10^{6} P M N$ \\
HBSS & $2.5 \pm 0.9$ & $0.7 \pm 0.2$ \\
Ab $1-15(250 \mu \mathrm{g} / \mathrm{ml})$ & $0.8 \pm 0.2(-70 \%)^{8}$ & $0.6 \pm 0.2(-19 \%)$ \\
$\begin{array}{l}\text { Control } \mathrm{IgG} \\
(250 \mu \mathrm{g} / \mathrm{ml})\end{array}$ & $2.7 \pm 0.6$ & $0.8 \pm 0.2$ \\
\hline
\end{tabular}

* Assay for chymotrypsin-like activity as hydrolysis of BTEE by $5 \times 10^{6} \mathrm{PMN}$ over $30 \mathrm{~min}$ at $37^{\circ} \mathrm{C}$.

${ }^{\ddagger}$ Assay for trypsin-like activity as hydrolysis of TAME as above.

${ }^{8}$ Significant difference from control $(P<0.05)$ for three experiments. 
Table II. Distribution of Marker Enzymes and Chymotrypsin-like Activity among Subcellular Fractions of Cavitated PMN

\begin{tabular}{|c|c|c|c|c|c|c|}
\hline Fraction & $\begin{array}{l}\text { Total cell } \\
\text { protein recovered }\end{array}$ & Lysozyme & $\begin{array}{l}\text { Alkaline } \\
\text { phosphatase }\end{array}$ & $\begin{array}{l}{ }^{3} \mathrm{H}-\mathrm{Con} \mathrm{A} \\
\text { recovered }\end{array}$ & $\begin{array}{l}\text { Chymotrypsin-like } \\
\text { activity }\end{array}$ & $\begin{array}{l}\text { Inhibition of } \\
\text { chymotrypsin-like } \\
\text { activity by } A b \quad 1-15\end{array}$ \\
\hline & $\%$ & $U / \mu g$ protein & $m U / \mu g$ protein & $\mathrm{cpm} / \mu \mathrm{g}$ protein & $m U / \mu g$ protein & $\%$ \\
\hline $\begin{array}{l}\text { Pellet 1, (nuclei, debris, } \\
\text { undisrupted PMN) }\end{array}$ & $31 \pm 14$ & $219 \pm 33$ & $125 \pm 6$ & 11.5 & $0.21 \pm .09$ & NT \\
\hline Pellet 2, (lysosome) & $13 \pm 5$ & $267 \pm 72$ & $144 \pm 2$ & 8.0 & $0.23 \pm .03$ & $56 \%$ \\
\hline Pellet 3, (membrane, ER) & $2 \pm 1$ & Below detection & $302 \pm 46^{*}$ & 37.7 & $0.16 \pm .04^{\ddagger}$ & $100 \%$ \\
\hline Supernatant 3, (cytosol) & $55 \pm 18$ & Below detection & Below detection & 1.9 & $0.04 \pm .01$ & $59 \%$ \\
\hline
\end{tabular}

Subcellular fractions were prepared by nitrogen cavitation of intact PMN and differential sedimentation at $1000 \mathrm{~g}$ (pellet 1), 27,000 g (pellet 2), and $105,000 \mathrm{~g}$ (pellet 3 ). For each fraction,, marker enzymes for cell organelles and chymotrypsin activity were assayed by standard techniques $(43,57,58)$. In studies of $\mathrm{Ab} \mathrm{1-15-mediated} \mathrm{inhibition,} 80 \mathrm{mU}$ each of chymotryptic activity from pellet 2, pellet 3 and supernatant 3 were incubated with substrate (BTEE) in the presence of $100 \mu \mathrm{g} / \mathrm{ml}$ of $\mathrm{Ab} 1-15$ or control $\mathrm{IgG}$. NT = not tested. Mean values \pm standard error of the mean are reported from three experiments. The data for ${ }^{3} \mathrm{H}$-Con $\mathrm{A}$ labeling and enzyme inhibition are the means of two experiments. ${ }^{*}$ Significantly greater than alkaline phosphatase activity of pellet $2, P<0.05$. ${ }^{\ddagger}$ Significantly greater than chymotrypsin activity of supernatant 3 , $P<0.05$.

noninhibitory concentrations of either ATEE $(5-25 \mu \mathrm{M})$ or BTEE (1-5 $\mu \mathrm{M})$ before exposure to minimal inhibitory concentrations of $\mathrm{Ab} 1-15(25-125 \mu \mathrm{g} / \mathrm{ml}$, titrated for each cell donor) or the equivalent amount of control monoclonal. It was found that PMNs exposed to buffer, then exposed to control $\mathrm{IgG}$, yielded a mean of $8.40 \pm 0.7 \mathrm{nmol} \mathrm{O}_{2}^{-} / 10 \mathrm{~min}$ in the presence of $0.5 \mu \mathrm{M}$ FMLP (mean of three experiments). By contrast, buffertreated cells added to Ab 1-15 produced only $6.10 \pm 1.0 \mathrm{nmol}$ $\mathrm{O}_{2}^{-} / 10 \mathrm{~min}$, a $27 \%$ inhibition in $\mathrm{O}_{2}^{-}$release $(P<0.05)$. Cell preexposure to ATEE did not significantly alter the effect of $\mathrm{Ab}$ 1-15: ATEE pretreated cells exposed to control IgG produced $8.84 \pm 1.0 \mathrm{nmol} \mathrm{O}_{2}^{-} / 10 \mathrm{~min}$, whereas ATEE pretreated cells exposed to $\mathrm{Ab} 1-15$ released $5.25 \pm 1.0 \mathrm{nmol} \mathrm{O}-1 / 10 \mathrm{~min}$. Although somewhat greater in magnitude, the Ab 1-15-mediated inhibition $($ mean $=41 \%$ ) of superoxide release from ATEE pretreated cells was not significantly different from Ab 1-15 inhibition (27\%) of medium pretreated cells from the same donors. Furthermore, it was apparent that concentrations of substrate in 35-100 fold excess of antibody concentration did not block the inhibitory effect of $\mathrm{Ab} 1-15$ on $\mathrm{O}_{2}^{-}$production. Results with BTEE were comparable: $\mathrm{Ab}$ 1-15 mediated a mean $40 \%$ inhibition of $\mathrm{O}_{2}^{-}$ production by cells preincubated with buffer vs. a $56 \%$ inhibition for cells preincubated with BTEE.

Effect of Ab 1-15 on highly purified pancreatic proteases. The effect of Ab 1-15 on the activity crystalline bovine chymotrypsin and trypsin was examined next. Compared with the effects of control monoclonal antibody, preincubation of bovine chymotrypsin with $\mathrm{Ab} \mathrm{1-15}(250 \mu \mathrm{g} / \mathrm{ml})$ resulted in a mean $57 \%$ decrease in the enzyme's ability to hydrolyze its substrate. In three separate experiments, the specific activity of bovine chymotrypsin was $44 \pm 12 \mathrm{U} / \mathrm{mg}$ in control $\mathrm{IgG}$, whereas in the presence of $\mathrm{Ab} 1-15$, specific activity decreased to $19 \pm 6 \mathrm{U} / \mathrm{mg}$ ( $P$ $<.001)$. In parallel experiments, an inhibitory effect on trypsin activity was not detected $(691 \pm 123 \mathrm{U} / \mathrm{mg}$ in control IgG vs. $617 \pm 99 \mathrm{U} / \mathrm{mg}$ in $\mathrm{Ab} \mathrm{1-15}$, NS). Lineweaver-Burk analysis of the effects of $100 \mu \mathrm{g} / \mathrm{ml} \mathrm{Ab} 1-15$ on bovine chymotrypsin activity indicated that this antibody modified both the $V_{\max }$ and $K_{\mathrm{m}}$ of the enzyme (Fig. 2). The pattern of inhibition, (a parallel upward shift of the kinetic plot) suggests an uncompetitive inhibition of the enzyme by $\mathrm{Ab} 1-15$. The $K_{\mathrm{I}}$ of $\mathrm{Ab} 1-15$ for chymotrypsin was $39 \mu \mathrm{M}$.
Immunologic cross-reactivity of Ab 1-15 for chymotrypsinlike peptides was demonstrated by specific immunoprecipitation of bovine $\alpha$-chymotrypsin (Fig. 3). Denaturation of bovine chymotrypsin at $100^{\circ} \mathrm{C}$ for 5 min abolished $\mathrm{Ab} 1-15$ recognition of the enzyme in the immunoprecipitation reaction.

Effects of $A b$ 1-15 and chymotrypsin on intermediate pathways of PMN activation. We next examined the effects of $\mathrm{Ab} 1-$ 15 versus those of chymotrypsin on PMN cAMP response. Because earlier observations demonstrated that protease treatment of other cell lines significantly alters their cAMP response to stimulation $(29,30)$, we examined antibody and enzyme effects on PMN cAMP response to two receptor-dependent stimuli, FMLP and isoproterenol. Neither Ab 1-15 nor chymotrypsin had a significant effect on cAMP levels in unstimulated PMN, however PMN preincubation with Ab 1-15 significantly enhanced $(P<0.05)$ cAMP accumulation after cell stimulation with either isoproterenol $(10 \mu \mathrm{M})$ or FMLP $(1 \mu \mathrm{M})(51$ and $35 \%$, respectively, Fig. 4). By contrast, exposure of neutrophils to chymotrypsin $(10 \mu \mathrm{g} / \mathrm{ml})$ before challenge significantly inhibited their cAMP response (by 19, [isoproterenol] and 31\% [FMLP], $P<0.05$, Fig. 5). PMN preincubation with pertussis toxin (500 $\mathrm{ng} / \mathrm{ml}$ ) reduced the chymotrypsin-mediated inhibition of PMN cAMP response to isoproterenol but had no effect on chymotrypsin's inhibition of cAMP response to FMLP (Fig. 5). Neither $\mathrm{Ab} 1-15$ preincubation nor chymotrypsin exposure altered cAMP response to the adenylate cyclase activator, forskolin (data not shown).

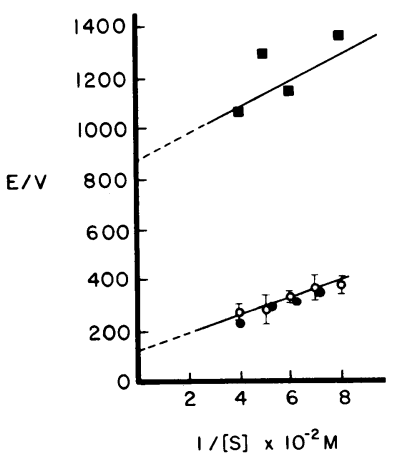

Figure 2. Lineweaver-Burk plot of Ab 1-15-mediated inhibition of bovine $\alpha$-chymotrypsin. $2 \mu \mathrm{g}$ enzyme $(0.12 \mathrm{U})$ was incubated with varying concentrations of the synthetic substrate BTEE in the absence (open circles) or presence of

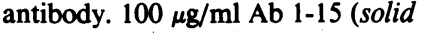
squares, $r=0.75)$ altered maximum velocity $\left(V_{\max }\right)$ and substrate affinity $\left(K_{\mathrm{m}}\right)$ whereas control IgG (solid circles, $r=0.96$ ) did not. The apparent $K_{\mathrm{I}}$ for Ab 1-15 was $39.3 \mu \mathrm{M}$. 


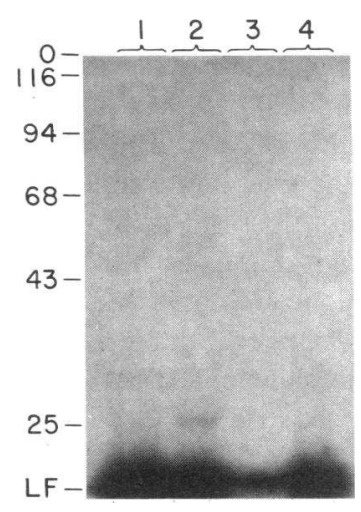

Figure 3. Immunoprecipitation of ${ }^{125} \mathrm{I}$ labeled chymotrypsin with $\mathrm{Ab}$ 1-15. $100 \mu \mathrm{g}$ of purified IgG (Ab 1-15 or control) was incubated with $20 \mu \mathrm{g}$ of precleared ${ }^{125}$ I-labeled chymotrypsin for $2 \mathrm{~h}$ at $37^{\circ} \mathrm{C}$. Immune complexes were recovered using $100 \mu \mathrm{g}$ precipitating sheep anti-mouse antibody (18 $h$ at $4^{\circ} \mathrm{C}$ ), then washed three times, and separated by SDS PAGE. Autoradiography reveals immunoprecipitation of ${ }^{125}$ I-chymotrypsin by $\mathrm{Ab} 1-15$ (lane 2) but not irrelevant IgG (lane 3). Neither antibody bound heat denatured $\left(100^{\circ} \mathrm{C}\right.$ for $\left.5 \mathrm{~min}\right)$ enzyme (lanes 1 and 4).

\section{Discussion}

The results of this study provide a biochemical mechanism for the inhibitory effects of $\mathrm{Ab}$ 1-15, an anti-neutrophil monoclonal antibody. Prior studies have demonstrated that PMN exposure to Ab 1-15 inhibits cell effector responses to FMLP and phorbol ester, and that this antibody immunoprecipitates a single 180,000-mol-wt component of PMN membrane (19). In the current study, the presence of $\mathrm{Ab} \mathrm{1-15}$ was found to reduce FMLP-induced $\mathrm{PMN} \mathrm{O}_{2}^{-}$production in a dose-dependent manner. The rate of $\mathrm{O}_{2}^{-}$generation was reduced, without effects on onset or duration of $\mathrm{O}_{2}^{-}$response. Furthermore, $\mathrm{F}\left(\mathrm{Ab}^{\prime}\right)_{2}$ dimer and $\mathrm{Fab}^{\prime}$ monomer of $\mathrm{Ab}$ 1-15 reproduced the effects of the intact $\mathrm{Ab}$ 1-15 $\mathrm{IgG}_{1}$ molecule, indicating that the function-inhibiting effects of the antibody are related to its antigen-combining site, and are less likely due to cross-linking of PMN surface antigens with consequent preactivation of the cell.

The Ab 1-15-mediated inhibition of chemotactic factor-induced PMN superoxide response was incomplete, with a $60 \%$ maximum reduction in superoxide response at the highest concentrations of $A b$ 1-15. This raises the possibility that a specific subpopulation of PMN binds and is inhibited by Ab 1-15, while another subpopulation, not bound by $\mathrm{Ab} 1-15$, continues to respond normally to FMLP stimulation. However, flow cytometry studies with fluorescein-conjugated antibody have indicated

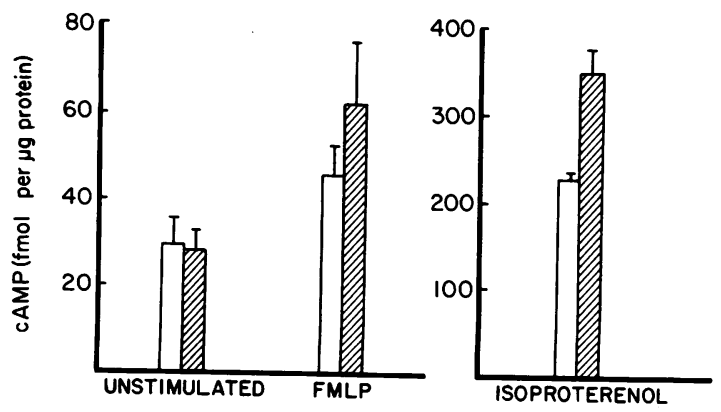

Figure 4. Ab 1-15 effects on stimulated PMN cAMP response. Intracellular cAMP accumulation by $10^{6} \mathrm{PMN}$ in the presence of the phosphodiesterase inhibitor isobutylmethylxanthine was measured at 2 min for cells incubated with buffer, $10^{-6} \mathrm{M}$ FMLP, or $10^{-5} \mathrm{M}$ isoproterenol. cAMP accumulation was significantly enhanced $(P<0.05$ and $P<0.001$, respectively) for FMLP- and isoproterenol-stimulated cells pretreated with Ab 1-15 (25 $\mu \mathrm{g} / 10^{6} \mathrm{PMN}$ ) (shaded bars) vs. control IgG (open bars). Data are mean \pm SE for three to five experiments.

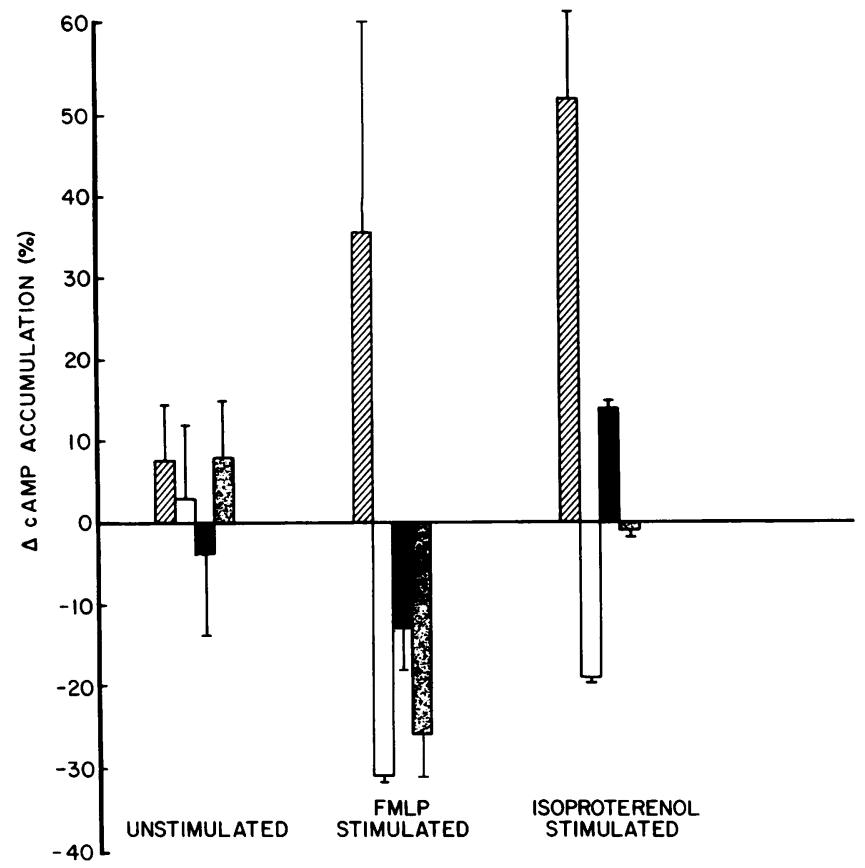

Figure 5. Effects of Ab 1-15 vs. chymotrypsin on stimulated cAMP response. Shown are the net effects of PMN exposure to Ab 1-15 (25 $\mu \mathrm{g} /$ $\mathrm{ml}$, striped bars), $\alpha$-chymotrypsin $(10 \mu \mathrm{g} / \mathrm{ml}$, open bars), pertussis toxin $(1 \mathrm{~h}$ preincubation in $500 \mathrm{ng} / \mathrm{ml}$, solid bars) and pertussis toxin preincubation followed by chymotrypsin exposure (stippled bars) on 2 min cAMP accumulation by resting and FMLP $\left(10^{-6} \mathrm{M}\right)$ and isoproterenol $\left(10^{-5} \mathrm{M}\right)$-treated cells. Bars, mean percentage change from the cAMP levels of control cells incubated in irrelevant $\operatorname{IgG}_{1}$ or BSA (as appropriate) for three experiments. Lines, SEM. Ab 1-15 significantly enhanced $(P<0.001$ for isoproterenol, $P<0.05$ for FMLP) and chymotrypsin significantly depressed $(P<0.05)$ stimulated cAMP response. Preincubation with pertussis toxin was found to offset the effects of chymotrypsin on response to isoproterenol but not its effects on response to FMLP.

that $>90 \%$ of purified PMN bind Ab 1-15 (Sawyer, J. A., C. A. Peck, and C. H. King, unpublished data). An alternative explanation for the incomplete inhibition of PMN response is that the target inhibited by Ab 1-15 is only partly responsible for activation and/or regulation of superoxide response to FMLP. To resolve this issue we defined an enzymatic function for the membrane antigen bound by Ab 1-15 and compared Ab 1-15's effects with those of other inhibitors of PMN activation.

We chose to examine the effects of Ab 1-15 on protease activity because of the pattern of antibody-mediated inhibition of superoxide response. Like the protease inhibitors tosyl-phenylalanyl-chlormethyl ketone and aprotinin, Ab 1-15 partially reduced PMN superoxide production and enzyme release in response to FMLP $(21,23)$. Unlike calcium antagonists and calmodulin inhibitors (48), Ab 1-15 did not prolong the lag period of superoxide production. Furthermore, Ab 1-15 decreased secretory responses without inhibiting chemotactic response, in a manner similar to promoters of membrane fluidity such as butanol and pentanol (49). Our results demonstrate that Ab 1-15 reduces significantly the chymotrypsin-like activity of intact PMN, as well as the chymotrypsin-like activity of membraneenriched PMN fractions. Interference with cellular enzyme did not appear to be mediated through a direct interaction with the enzyme's active site, as excess (but noninhibitory) amounts of 
chymotrypsin substrate failed to protect neutrophils from the effects of $A b$ 1-15 on superoxide production. However, our results with bovine chymotrypsin indicate that $\mathrm{Ab}$ 1-15 acts as a noncompetitive inhibitor of enzyme activity. In our previous studies, we have found comparable levels of Ab 1-15-mediated inhibition whether cells were preincubated with $\mathrm{Ab}$ and then washed, or simply incubated with antibody at the time of stimulation (19). These findings suggest that under normal conditions enzyme activity susceptible to Ab 1-15 inhibition is active (20) at the time of stimulation, and is not activatable, i.e., elicited during the process of cell activation (23). The observed 2.7 milliU of chymotrypsin activity for one million PMN is equivalent to $\sim 10^{6}$ enzyme molecules per unstimulated cell, if a catalytic constant of $25 \mathrm{~s}^{-1}$ (equal to the $k_{\text {cat }}$ of $\alpha$-chymotrypsin for BTEE) is assumed (50). This estimate corresponds to the mean value of $6 \times 10^{5}$ antigen sites/cell measured in antibody binding saturation studies (51). Adding Ab 1-15 after the onset of FMLPinduced $\mathrm{O}_{2}^{-}$generation did not significantly inhibit this cell function. The kinetics of $\mathrm{Ab}$ 1-15 antigen movement suggest rapid surface turnover of the $\mathrm{Ab} 1-15$ target molecule: ${ }^{125} \mathrm{I}$-labeled $\mathrm{Ab} 1-15$ bound to cells is internalized within $5 \mathrm{~min}$ at $37^{\circ} \mathrm{C}$, however, the total number of surface binding sites on the PMN remains constant, even after cell activation with FMLP or calcium ionophore A23187 (51). Because failure to inhibit superoxide release under these conditions is not due to a lack of antigen targets, it appears that the Ab 1-15 antigen target may be involved only in the initiation of PMN superoxide generation and not its perpetuation.

The anti-chymotrypsin activity of $\mathrm{Ab}$ 1-15 demonstrated for PMN was further confirmed in studies with purified chymotrypsin enzyme. Ab 1-15 significantly inhibited the function of bovine $\alpha$-chymotrypsin and specifically immunoprecipitated this enzyme in its undenatured form. The availability of a specific anti-protease antibody offers an opportunity to reexamine the controversial role of membrane proteases in PMN activation. Early studies of phosphonate ester-mediated inhibition of PMN chemotaxis suggested that PMN protease is essential for cellular activation (20). Further studies using protease inhibitors, whether macromolecular (aprotinin, soybean trypsin inhibitor) or micromolecular (synthetic ester) apparently confirmed the prostimulatory function of PMN chymotrypsin-like proteases (21$23,25)$. In these studies, chymotrypsin-specific inhibitors, such as tosyl phenyl chlormethyl ketone, and chymotrypsin substrates (such as BTEE), demonstrated significantly greater inhibition of PMN functions than other protease inhibitors $(21,23)$. However, it appears that some of the effects of protease inhibitors on intact cells may be nonspecific. In most studies, protease inhibitors have been used in high concentration (0.1-1.0 mM), making it possible that inhibitor-mediated effects are due to several nonspecific factors, including inhibition of nonproteolytic esterases, changes in membrane fluidity, inhibitor-mediated protein alkylation or inhibitor-mediated phosphorylation (reviewed in reference 26). Results of PMN inhibition studies using macromolecular protease inhibitors (which are excluded from the cell) have been variable; one study of three highly purified soybean peptides showed an inverse correlation between protease inhibition by these peptides and their inhibition of PMN effector responses (26).

As a means of defining a function-associated PMN protease, Ab 1-15 offers several distinct advantages. In contrast to low molecular weight protease inhibitors, the $A b 1-15$, because of its size and target specificity, has effects that are probably limited to surface structures. In addition, its interaction with proteins is not covalent. In micromolar concentrations, the antibody alters different aspects of FMLP- and PMA-induced cellular response without affecting cell activation by opsonized particles or by activated complement (19). In our inhibition studies, we excluded the nonspecific effects of solvents, $\mathrm{pH}$, and osmolarity by dissolving $\mathrm{Ab} 1-15$ in cell buffer and by using a similarly processed, isotype-matched antibody in all control assays. The cell inhibitory effects of $\mathrm{Ab}$ 1-15 are not due to heterologous desensitization, as antibody exposure alone did not activate superoxide or degranulation responses (19), neither did it significantly alter resting cAMP levels or membrane potential (King, C. H., and C. S. H. Goralnik, unpublished data).

Three distinct chymotryptic proteases of low molecular weight $(20-25,000)$ have been isolated from the granules of human neutrophils $(52,53)$. Furthermore, Tsung et al. have described a large ( 200,000-mol-wt) chymotryptic protease that copurifies with membranes of rabbit PMN (24). Our previous immunoprecipitation data, indicating $A b$ 1-15 recognition of a 180,000-mol-wt PMN surface molecule (19), and our present cell fractionation and enzyme inhibition data suggest that $\mathrm{Ab}$ 1-15 recognizes an analogous high molecular weight protease within purified human PMN membranes. Although this membrane protease is the most likely target for $\mathrm{Ab}$ 1-15-mediated inhibition when cells are intact, we noted that $A b$ 1-15 also partially inhibits the chymotryptic activity associated with cell granule fractions and cytosol. It is not known whether this latter effect also contributes to $\mathrm{Ab} 1-15$-mediated inhibition of cellular function.

In other cells, exposure of cell membranes to chymotrypsin provides differential enhancement or depression of the function of the GTP-dependent $N$ proteins $(29,30)$. In PMN, pertussis toxin, an inhibitor of the $N_{\mathrm{i}}$ molecule, inhibits FMLP-induced PMN activation in assays of chemotactic and secretory response $(9,12-14)$. The latter finding suggests that the $N_{\mathrm{i}}$ molecule is an important intermediary in FMLP receptor-mediated cell stimulation. We sought, therefore, to determine whether the chymotryptic activity recognized by $\mathrm{Ab} 1-15$ might act to stimulate cells by enhancing the function of the $N_{\mathrm{i}}$ molecule during the early stages of membrane activation. We hypothesized that if the Ab 1-15-identified protease served to activate the $N_{\mathrm{i}}$ molecule, then antibody-mediated inhibition of this protease could reduce different $N_{\mathrm{i}}$-dependent PMN functional responses to FMLP stimulation, such as superoxide anion generation and degranulation, as previously demonstrated (19). Additionally, protease inhibition might also enhance cAMP response to the beta-adrenergic agonist isoproterenol through a reduction of isoproterenol's $N_{\mathrm{i}}$ activation (54) and a consequent decrease in $N_{\mathrm{i}}$-mediated effects on adenylate cyclase. We found that $\mathrm{Ab} 1-$ 15 did indeed enhance cAMP accumulation in response to isoproterenol and to FMLP, and by contrast, that chymotrypsin treatment significantly reduced cAMP response to both of these surface receptor-dependent stimuli. However, when cells were treated with pertussis toxin to block the function of the $N_{\mathrm{i}}$ molecule, the inhibitory effect of chymotrypsin on cAMP response to FMLP remained unchanged. The net effect of chymotrypsin on the response of toxin-treated PMN to isoproterenol was $<5 \%$, suggesting a merely additive offsetting (by chymotrypsin) of the enhancing effect of pertussis toxin. Although Lad et al. (9) have implicated the $N_{\mathrm{i}}$ molecule as mediator in the FMLP-mediated reduction of forskolin-stimulated adenylate cyclase activity, Verghese et al. (55) have recently demonstrated that in the intact 
cell, FMLP-mediated alternation in CAMP levels do not appear to depend on $N$ molecule regulation. Rather, this down-regulation of CAMP accumulation appears to depend on calciumdependent events that modify phosphodiesterase activity. Taken together, these findings suggest that multiple membrane events are associated with ligand occupancy of the FMLP receptor, and that certain of these events, (probably excluding $N_{\mathrm{i}}$ molecule activation,) are the consequence of the proteolytic function of a membrane-associate chymotryptic enzyme. Although recent evidence has suggested an association of the $A b$ 1-15 protease activity with the FMLP receptor (50), Ab 1-15 also inhibits PMN response to phorbol ester (a surface receptor-independent stimulus binding directly to protein kinase $C$ [56]) and augments cAMP response to isoproterenol. Therefore, the function of the Ab 1-15 antigen/protease is not uniquely associated with the function of the FMLP receptor, nor are its effects limited to a single facet of cell effector response.

In summary, our results demonstrate that molecules on the neutrophil surface, which enzymatically and immunologically resemble chymotrypsin, are involved in cellular response to FMLP, isoproterenol, and phorbol ester. Their function appears to be the alteration and activation of second messenger pathways situated in the PMN membrane. Further analysis of the role of $\mathrm{Ab}$ 1-15 antigen in membrane pathways of PMN activation will allow a better definition of the mechanisms of stimulus-response coupling in neutrophil activation.

\section{Acknowledgments}

We thank Dr. J. W. Kazura for his advice and technical assistance. Our thanks also to B. Jackson for help with preparation of the manuscript.

This work was supported, in part, by grants from U. S. Public Health Service (AI 15351 and DK 01404), the Rockefeller Foundation, the Kidney Foundation of Ohio, and the American Heart Association, Northeast Ohio Affiliate.

\section{References}

1. Goetzl, E., D. Foster, and D. Goldman. 1981. Isolation and partial characterization of membrane protein constituents of human neutrophil receptors for chemotactic formylmethionyl peptides. Biochemistry. 20: 5717-5722.

2. Fleit, H. B., S. D. Wright, and J. C. Unkeless. 1982. Human neutrophil Fc receptor distribution and structure. Proc. Natl. Acad. Sci. USA. 79:3275-3279.

3. Arnaout, M. A., R. Todd III, N. Dana, J. Melamed, S. F. Schlossman, and H. R. Colten. 1983. Inhibition of phagocytosis of complement C3- or immunoglobulin G-coated particles and of C3bi binding by monoclonal antibodies to a monocyte-granulocyte membrane glycoprotein (Mol). J. Clin. Invest. 72:171-179.

4. Fletcher, M. P., B. E. Seligmann, and J. I. Gallin. 1982. Correlation of human neutrophil secretion, chemoattractant receptor mobilization, and enhanced functional capacity. J. Immunol. 128:941-948.

5. Smith, C. D., B. C. Lane, I. Kusaka, M. W. Verghese, and R. Snyderman. 1985. Chemoattractant receptor-induced hydrolysis of phosphatidylinositol-4,5-bisophosphate in human polymorphonuclear leukocyte membranes. J. Biol. Chem. 260:5875-5878.

6. Hirata, F., B. A. Corcoran, K. Venkatasubramanian, E. Schiffman, and J. Axelrod. 1979. Chemoattractants stimulate degradation of methylated phospholipids and release of arachadonic acid in rabbit leukocytes. Proc. Natl. Acad. Sci. USA. 76:2640-2643.

7. Walsh, C. E., B. M. Waite, M. J. Thomas, and L. R. DeChatelet. 1981. Release and metabolism of arachadonic acid in human neutrophils. J. Biol. Chem. 256:7228-7234.
8. Smolen, J. E., H. M. Korchak, and G. Weissmann. 1980. Increased levels of cyclic adenosine $3^{\prime}-5$ ' monophosphate in human polymorphonuclear leukocytes after surface stimulation. J. Clin. Invest. 65:10771085.

9. Lad, P. M., C. V. Olson, and P. A. Smiley. 1985. Association of the N-formyl-met-leu-phe receptor in human neutrophils with a GTPbinding protein sensitive to pertussis toxin. Proc. Natl. Acad. Sci. USA. 82:869-873.

10. Sklar, L. A., P. A. Hyslop, Z. G. Oades, G. M. Omann, A. J. Jesaitis, R. G. Painter, and C. G. Cochrane. 1985. Signal transduction and ligand-receptor dynamics in the human neutrophil. J. Biol. Chem. 260:11461-11467.

11. Korchak, H. M., C. Wilkenfield, A. M. Rich, A. R. Radin, K. Vienne, and L. E. Rutherford. 1984. Stimulus response coupling in the human neutrophil. J. Biol. Chem. 259:7439-7445.

12. Volpi, M., P. H. Naccache, T. F. P. Molski, J. Shefcyk, C.-K. Huang, M. L. Marsh, J. Munoz, E. L. Becker, and R. I. Shaafi. 1985. Pertussis toxin inhibits fmet-leu-phe but not phorbol ester-stimulated changes in rabbit neutrophils: role of $\mathrm{G}$ proteins in excitation response coupling. Proc. Natl. Acad. Sci. USA. 82:2708-2712.

13. Becker, E. L., J. C. Kermode, P. H. Naccache, R. Yassin, M. L. Marsh, J. J. Munoz, and R. I. Shaafi. 1985. The inhibition of neutrophil granule enzyme secretion and chemotaxis by pertussis toxin. J. Cell Biol. 100:1641-1646.

14. Smith, C. D., C. C. Cox, and R. Snyderman. 1986. Receptorcoupled activation of phosphoinositide-specific phospholipase $\mathrm{C}$ by an N protein. Science (Wash. DC). 232:97-100.

15. Cotter, T. G., P. J. Keeling, and P. M. Henson. 1981. A monoclonal antibody inhibiting FMLP-induced chemotaxis of human neutrophils. J. Immunol. 127:2241-2244.

16. Beatty, P. G., J. A. Ledbetter, P. J. Marin, T. H. Price, and J. A. Hansen. 1983. Definition of a common leukocyte cell surface antigen (Lp 95-150) associated with diverse cell mediated immune functions. $J$. Immunol. 131:2913-2918.

17. Martin, L. S., D. S. Gordon, M. E. Wilson, S. W. Browning, and R. B. Fritz. 1984. Monoclonal antibody to human granulocytes: cellular specificity and functional studies. J. Leukocyte Biol. 35:265-279.

18. Painter, R. G., L. A. Sklar, A. J. Jesaitis, M. Schmitt, and C. G. Cochrane. 1984. Activation of neutrophils by $\mathrm{N}$-formyl chemotactic peptides. Fed. Proc. 43:2737-2742.

19. King, C. H., C. A. Peck, C. S. Haimes, J. W. Kazura, P. J. Spagnuolo, J. A. Sawyer, G. R. Olds, and A. A. F. Mahmoud. 1986. Modulation of human neutrophil effector functions by monoclonal antibodies against surface membrane molecules of 94,000 and 180,000 molecular weight. Blood. 67:188-194.

20. Becker, E., and P. Ward. 1967. Partial biochemical characterization of the activated esterase required in the complement-dependent chemotaxis of rabbit polymorphonuclear leukocytes. J. Exp. Med. 125: 1021-1030.

21. Duque, R., S. Phan, M. Sulavik, and P. Ward. 1983. Inhibition by tosyl-L-phenylalanyl choromethyl ketone of membrane potential changes in rat neutrophils. J. Biol. Chem. 258:8123-8128.

22. Kitagawa, S., F. Takaku, and S. Sakamoto. 1979. Possible involvement of proteases in superoxide production by human polymorphonuclear leukocytes. FEBS (Fed. Eur. Biochem. Soc.) Letters. 99:275278.

23. Kitagawa, S., F. Takaku, and S. Sakamoto. 1980. Evidence that proteases are involved in superoxide production by human polymorphonuclear leukocytes and monocytes. J. Clin. Invest. 65:74-81.

24. Tsung, P.-K., S. Kegeles, and E. Becker. 1978. The evidence for the existence of chymotrypsin-like esterase activity in the plasma membranes of rabbit neutrophils and the specific chemotactic peptide binding activity of the subcellular fractions. Biochim. Biophys. Acta. 541:150160.

25. Goldstein, B. D., G. Witz, M. Amoruso, and W. Troll. 1979. Protease inhibitors antagonize the activation of polymorphonuclear leukocyte oxygen consumption. Biochem. Biophys. Res. Commun. 898: 854-860. 
26. Abramovitz, A., J. Yavelow, V. Randolph, and W. Troll. 1983. Inhibition of superoxide production in human neutrophils by purified soybean polypeptides. J. Biol. Chem. 258:15153-15157.

27. Niewiarowski, S., A. Z. Budzynski, T. A. Morinelli, T. M. Brudzynski, and G. J. Stewart. 1981. Exposure of fibrinogen receptors on human platelets by proteolytic enzymes. J. Biol. Chem. 256:917-925.

28. Lynch, G., and M. Baudry. 1984. The biochemistry of memory: a new and specific hypothesis. Science (Wash. DC). 224:1057-1063.

29. Hanoune, J., D. Stengel, and M.-L. Lacombe. 1983. Proteolytic activation and solubilization of adenylate and guanylate cyclases. $\mathrm{Mol}$. Cell. Endocr. 31:21-41.

30. Muramaya, T., and M. Ui. 1985. Receptor-mediated inhibition of adenylate cyclase and stimulation of arachadonic acid release in 3T3 fibroblasts. J. Biol. Chem. 260:7226-7233.

31. Zimmerman, G. A., T. M. McIntyre, and S. M. Prescott. 1985. Thrombin stimulates the adherence of neutrophils to human endothelial cells in vitro. J. Clin. Invest. 76:2236-2246.

32. Speer, C. P., M. J. Pabst, H. B. Hedegaard, R. F. Rest, and R. B. Johnston, Jr. 1984. Enhanced release of oxygen metabolites by monocyte-derived macrophages exposed to proteolytic enzymes: activity of neutrophil elastase and cathespsin G. J. Immunol. 133:2151-2156.

33. Vischer, T. L., U. Bretz, and M. Bagglioni. 1976. In vitro stimulation of lymphocytes by neutral proteinases from human polymorphonuclear leukocyte granules. J. Exp. Med. 144:863-872.

34. Olsson, I. 1977. Biochemical properties of neutral proteases of human neutrophils. In Movement, Metabolism and Bactericidal Mechanisms of Phagocytes. F. Rossi, P. Patriarca and D. Romeo, editors. Piccin Medical Books, Padua, Italy. 103-115.

35. Tennant, J. R. 1964. Evaluation of the trypan blue technique for determination of cell viability. Transplantation. 2:685-694.

36. McKearn, T. T. 1980. Method for growing hybridomas in rats and mice. In Monoclonal Antibodies. R. Kennett, T. McKearn, and K. B. Bechtol, editors. Plenum Publishing Corp., New York. 403-404.

37. Bruck, C., D. Portelle, C. Glineur, and P. Boller. 1982. One step purification of mouse monoclonal antibodies from ascitic fluid by DEAE affigel blue chromatography. J. Immunol. Methods. 53:313-319.

38. Mason, D., and A. Williams. 1980. The kinetics of antibody binding to membrane antigens in solution and at the cell surface. Biochem. J. 187:1-20.

39. Lowry, O., N. Rosebrough, A. Farr, and R. Randall. 1951. Protein measurement with the folin phenol reagent. J. Biol. Chem. 193:265278.

40. Boyum, A. 1968. Isolation of mononuclear cells and granulocytes from human blood. Scand. J. Clin. Lab. Invest. 21(Suppl. 97): 77-89.

41. Hafeman, D. G., J. Lewis, and H. M. McConnell. 1980. Triggering of the macrophage and neutrophil respiratory burst by antibody bound to a spin-label phospholipid hapten in model lipid bilayer membranes. Biochemistry. 19:5387-5394.

42. Aswanikumar, S., E. Schiffmann, B. Corcoran, and S. Wahl. 1976. Role of a peptidase in phagocyte chemotaxis. Proc. Natl. Acad. Sci. USA. 73:2439-2442.

43. Hummel, B. 1959. A modified spectrophotometric determination of chymotrypsin, trypsin and thrombin. Can. J. Biochem. Physiol. 37: 1393-1399.

44. Klempner, M. S., R. B. Mikkelsen, D. H. Corfman, and J. AndreSchwartz. 1980. Neutrophil plasma membranes. I. High yield purification of human neutrophil plasma membrane vesicles by nitrogen cavitation and differential centrifugation. J. Cell Biol. 86:21-28.

45. Record, M., P. Laharrague, G. Fillola, J. Thomas, G. Ribes, P. Fontan, H. Chap, J. Corberand, and L. Douste-Blazy. 1985. A rapid isolation procedure of plasma membranes from human neutrophils using self-generating Percoll gradients. Importance of $\mathrm{pH}$ in avoiding contamination by intracellular membranes. Biochem. Biophys. Acta. 819:1-9.

46. Pierce Chemical Co. 1983. Iodobeads. Product Information Technical Bulletin. 1-4.

47. Sedor, J. R., and H. E. Abboud. 1985. Histamine modulates contraction and cyclic nucleotides in cultured rat mesangial cells. Differential effects mediated by histamine $\mathrm{H}_{1}$ and $\mathrm{H}_{2}$ receptors. J. Clin. Invest. 75:1679-1689.

48. Smolen, J. E. 1984. Lag period for superoxide anion generation and lysosomal enzyme release from human neutrophils: effects of calcium antagonists and anion channel blockers. J. Lab. Clin. Med. 104:1-10.

49. Yuli, I., A. Tomonaga, and R. Snyderman. 1982. Chemoattractant receptor functions in human polymorphonuclear leukocytes are divergently altered by membrane fluidizers. Proc. Natl. Acad. Sci. USA. 79: 5906-5910.

50. Walsh, K. A., and P. Wilcox. 1970. Serine proteases. Methods Enzymol. 19:31-41.

51. King, C. H., and P. J. Kleinhenz. 1986. Identification of a neutrophil surface "receptor" for N-formyl-met-leu-phe as a chymotrypsinlike protease. Clin. Res. 34:521A. (Abstr.)

52. DeWald, B., R. Rindler-Ludwig, U. Bretz, and M. Bagglioni. 1975. Subcellular localization and heterogeneity of neutral proteases in neutrophilic polymorphonuclear leukocytes. J. Exp. Med. 141:709-723.

53. Odeberg, H., I. Olsson, and P. Venge. 1975. Cationic proteins of human granulocytes. IV. Esterase activity. Lab. Invest. 32:86-90.

54. Asano, T., T. Katada, A. G. Gilman, and E. M. Ross. 1984. Activation of the inhibitory GTP-binding protein of adenylate cyclase, $\mathrm{Gi}$, by $\beta$-adrenergic receptors in reconstituted vesicles. J. Biol. Chem. 259:9351-9354.

55. Verghese, M. W., K. Fox, L. C. McPhail, and R. Snyderman. 1985. Chemoattractant-elicited alterations of cAMP levels in human polymorphonuclear leukocytes require a $\mathrm{Ca}^{+2}$-dependent mechanism which is independent of transmembrane activation of adenylate cyclase. J. Biol. Chem. 260:6769-6775.

56. Parker, P. J., L. Coussens, N. Totty, L. Rhee, S. Young, E. Chen, S. Stabel, M. D. Waterfield, and A. Ullrich. 1986. The complete primary structure of protein kinase C-the major phorbol ester receptor. Science (Wash. DC). 233:853-859.

57. Smolelis, A. N., and S. E. Hartwell. 1949. The determination of lysozyme. J. Bacteriol. 58:731-736.

58. DeChatelet, L. R., and M. R. Cooper. 1970. A modified procedure for the determination of leukocyte alkaline phosphatase. Biochem. Med. 4:61-68. 